\title{
KESANTUNAN BERBAHASA DALAM WACANA INTERAKSI KOMUNIKASI DI LINGKUNGAN UNIVERSITAS BENGKULU
}

\author{
Rokhmat Basuki \\ Universitas Bengkulu. \\ Email: rokhmat.b58@gmail.com
}

\begin{abstract}
Abstrak
Tujuan penelitian ini adalah untuk menemukan, mendeskripsikan dan menjelaskan kesantunan berbahasa dalam interaksi komunikasi di Universitas Bengkulu. Penektian ini menggunakan pendekatan kualitatif dengan menggunakan anaksis isi. Proses pengumpulan data dilakukan dengan menggunakan teknik penyadapan dengan merekam interaksi komunikasi yang dilakukan oleh masyarakat (civitas) akademik. Prosedur pengolahan data dilakukan dengan langkah pentransknpsian, pengklasifikasian data ke dalam korpus penelitian, penganaksisan percakapan terpikh dari korpus, dan penyimpulan hasil analisis. Hasil penelitian menggambarkan bahwa dalam interaksi komunikasi masyarakat akademik Universitas Bengkulu antara mahasiswa dengan dosen, memenuhi prinsip kesantunan, akan tetapi masih terdapat pelanggaran terhadap prinsip kesantunan tersebut. Strategi yang digunakan menggambarkan strategi positif dan negatif, sedangkan sebagai penanda kesantunan digunakan bentuk menyampaian pertanyaan, terima kasih, memuliakan Tuhan, menyampaikan maaf, mendoakan orang lain, dan menyampaikan kesetujuan.
\end{abstract}

Kata Kunci: pragmatik, interaksi komunikasi, kesantunan berbahasa

\begin{abstract}
The aim of the research is to describe language politeness in interaction comumunication discourse in Bengkulu University. The focus of the research is to determine how to fulfill the maxim, violation the maxim, strategies, markers, andform of direct and indirect speech in language politeness. This research used a qualitative approach by using content analysis methods and inductive procedures. The data collecting technique by recording conversation, noted conversation, classify convertations into research corpus, and selected Conversation unit from research corpus as an anali ${ }^{\wedge}$ d data unit. The result of research showed in discourse interaction communication at University of Bengkulu, between student and dosen fulfill the principle of maxim, also violation of the principle of language politeness.
\end{abstract}

Keyword: pragmatics, interaction communication, language politeness.

\section{PENDAHULUAN}

Berbahasa menempati kedudukan penting dalam kehidupan manusia untuk membentuk interaksi antarpribadi dan memelihara hubungan sosial. Tujuan berbahasa bukan semata-mata untuk saling bertukar informasi saja, melainkan unmk menunjukkan keterkaitan sosial yang lebih baik antara seseorang dengan orang lain dan antara orang dengan lingkungannya. Dalam kaitan itu Grice (1981: 10) mengatakan bahwa suksesnya percakapan bergantung tidak hanya pada apa yang dikatakan penumr, tetapi juga pada seluruh pendekatan interaksi. Seorang penutur (yang selanjutnya disingkat Pn) ketika berkomunikasi, secara tidak sadar berkecenderungan memikh kosa kata yang akan diujarkan. Kejadian seperti ini dilakukan karena pertimbangan siapa mitra mturnya (yang selanjutnya disingkat $\mathrm{Mt}$ ), di mana dan kapan tuturan itu dilakukan, serta bagaimana situasi dalam komunikasi tersebut Unmk itu, kesantunan berbahasa diperlukan oleh setiap orang dalam berinteraksi agar ter jalin komunikasi yang baik. Kesanmnan berbahasa dapat dilihat ketika seseorang berinteraksi dengan orang kin, baik individu maupun kelompok.

Bahasa yang digunakan masyarakat (civitas) akademika adalah bahasa baku yang memiliki ciriciri yang khas yaitu singkat, jelas, padat, sederhana, lancar, lugas, dan menarik. Ciri khas ini tentunya juga harus terkait dengan etika komunikasi atau keterampilan manusia dalam betbahasa sangat dibutuhkan demi tetciptanya hubungan yang baik antarsesama. Manusia 
memerlukan betbagai cara untuk dapat menyampaikan gagasannya.

Kaidah atau aturan yang harus diperhatikan Pn demi tujuan berkomunikasi yang baik adalah dengan cara memperhatikan situasi dan kondisi berbahasa penutur. Hal itu yang membuat situasi berbahasa dalam berkomunikasi sangat penring, karena bahasa yang baik adalah bahasa yang dapat menyampaikan pesan dalam situasi berbahasa saat berkomunikasi. Situasi berbahasa ini akan menentukan aturan yang akan mengatur $\mathrm{Pn}$ bahasa untuk dapat menyampaikan informasi atau gagasan dengan jelas dan tidak terjadi kesalahpahaman dalam berkomunikasi. Bagaimana Pn dapat menjaga hubungan komunikasi yang baik dengan Mt atau bagaimana cara Pn memperlakukan Mt pada saat berkomunikasi, merupakan bagian dari penentu kelancaran dalam berkomunikasi.

Terjadinya komunikasi yang baik dan tidak menimbulkan kesalahpahaman dalam komunikasi akan dipengaruhi oleh bagaiman Pn dalam memenuhi atau tidak memenuhi kaidah-kaidah atau aturan-aturan dalam berkomunikasi, yaitu terpenuhi atau tidaknya aturan situasi dalam bertutur. Dengan demikian, dalam berkomukiasi seringkali tidak tercipta hubungan komunikasi yang baik dalam memahami simasi bertutur.

Dengan demikian, yang harus diperhatikan Pn dalam komunikasi, tidak hanya sekedar mematuhi aturan kerja sama atau demi terjadi kesepahaman, tapi juga perlu saling menghormati, tidak merugikan satu sama lain, dan tidak mengancam satu sama lain. Jadi, yang diperlukan adalah aturan-aturan selain aturan kerja sama, yaitu aturan kesantunan berbahasa atau prinsip kesantunan (Leech, 1982: 132). Aturan kesantunan yang dimaksud adalah aturan dalam menjaga hubungan interaksional antar Pn agar tetap terjaga hubungan personal yang saling menghormati, tidak merugikan dan tidak mengancam muka satu sama lain.

Seseorang dalam berkomunikasi mempunyai strategi. Setiap Pn mempunyai ciri berbeda saat komunikasi berjalan. Ciri tersebut adalah bagaiman Pn itu menempatkan dirinya sebagai salah satu pembentuk komunikasi. Dengan kata lain bahwa ada berbagai macam cara atau strategi yang ditempuh Pn saat berlangsungnya komunikasi. Pertama, penutur dalam komunikasinya akan bertindak mematuhi maksim yang ada, dan membuat percakapan tersebut menjadi percakapan yang terjadi kesepahamaan maksud. Kedua, dapat ditemukan dalam peristiwa komunikasi sehari-hari, Pn seringkali melanggar maksim sehingga terjadi kesalahpahaman antar
Pn. Ketiga, dapat ditemui pada peristiwa komunikasi bahwa Pn dalam strategi komunikasinya juga dapat menyesuaikan dirinya. Artinya Pn bisa mematuhi maksim atau juga bisa melanggar maksim, itu tergantung dengan siapa penutur berkomunikasi. Keempat, seringkali ditemui bahwa Pn selalu berupaya untuk menyampaikan komunikasi apa adanya sesuai fakta. Informasi disampaikan dengan jelas, ringkas bahkan tertib. Strategi Pn demikian dinamakan dengan strategi memahami maksim. Yang terakhir, banyak Pn yang dengan sengaja tidak memperdulikan maksim, padahal ia telah mengetahui bahwa aturan itu harus dipatuhinya untuk menciptakan hubungan komunikasi yang baik. Strategi yang ditempuh Pn itu adalah strategi melecehkan maksim (Achmad, 2002: 5).

Penjabaran di atas merupakan bagian dari strategi-strategi berkomunikasi yang seharusnya dipakai para penutur bahasa demi terciptanya hubungan yang baik, dalam kehidupan bermasyarakat. Untuk itu, dalam bentuk komunikasi sehari-hari yang diperlukan adalah penyesuaian dalam kesepakatan untuk mematuhi aturan percakapan atara Pn dan Mt.

Sivitas akademika universitas Bengkulu merupakan masyarakat akademis yang dapat dikatakan terpelajar, namun demikian bagaimana interaksi dalam komunikasi di lingkungan Universitas Bengkulu tersebut, hendaknya menjaga keselarasan hubungan dengan menghargai siapapun yang menjadi Mt-nya.

Fokus penelitian ini adalah kesantunan berbahasa dalam interaksi komunikasi di lingkungan Universitas Bengkulu, yang dapat dirinci menjadi subfokus sebagai berikut; (1) bagaimana pemenuhan maksim, dan (2) bagaimana pelanggaran maksim kesantunan dalam interaksi komunikasi di lingkungan Universitas Bengkulu.

Prinsip utama suatu komunikasi adalah penyampaian informasi yang jelas antara $\mathrm{Pn}$ dan Mt Wujud informasi mengacu pada pendekatan Brown dan Levinson (1973) dan Leech (1982) rang membahas kesantunan dilihat dari norma sosial dan penggunaan sumber daya linguistik dalam kesantunan berbahasa yang mereka kemukakan, dan mempunyai rumusan yang tetap.

Hymes (1968:99) mengatakan bahwa komunikasi disebutnya dengan akronim speaking, sehingga semua konteks ujaran saling terkait untuk memahami makna ujaran. Sebagai cara memahami ujaran dengan melihat satu atau beberapa konteks dapat membantu memahami makna suatu ujaran dalam wacana. 
Menurut Searle (1969:78), dalam semua komunikasi linguistik terdapat tindak tutur. Lebih lanjut Searle berpendapat bahwa komunikasi linguistik bukan sekedar lambang, kata atau kalimat, tetapi akan lebih tepat apabila disebut hasil atau produk dari lambang, kata atau lcalimat vang berujud perilaku tindak mtur \{theperformance of speech acts). Dengan kata lain untuk lebih tegasnya tindak tutur adalah hasil atau produk dari suatu kalimat dalam kondisi tertentu dan merupakan kesatuan terkecil dari komunikasi linguistik. Seperti dalam komunikasi linguistik vang terdapat bentuk-bentuk pertanyaan, pernyataan dan perintah, maka dalam teori tindak tutur juga dapat pula berujud pertanyaan, pernyataan dan perintah.

Dalam pemakaian bahasa, tindak tutur, berhubungan dengan peristiwa mtur, yaitu setiap penutur akan selalu memperhimngkan kepada siapa ia akan berbicara, di mana, mengenai masalah apa dan dalam suasana bagaimana. Dengan demikian maka tempat bicara akan menentukan cara-cara pemakaian bahasa penutur, demikian juga pokok pembicaraan dan situasi bicara akan memberikan warna pula terhadap pembicaraan yang sedang berlangsung. Keseluruhan peristiwa pembicaraaan dengan segala faktor serta peranan faktor-faktor tersebut dalam peristiwa tutur disebut dengan istilah peristiwa tutur (speech event). Peristiwa semacam ini akan tampak dalam suatu diskusi.

Beberapa ulasan Fraser (1978) mengenai definisi kesantunan yaitu pertama, kesantunan itu adalah properti atau bagian dari ujaran; jadi bukan ujaran itu sendiri. Kedua, pendapat pendengarlah yang menentukan apakah kesantunan itu ada pada suatu ujaran. Mungkin saja sebuah ujaran dimaksudkan sebagai ujaran yang santun oleh si penutur, tetapi di telinga si pendengar ujaran itu ternyata tidak terdengar santun, dan demikian pula sebaliknya. Ketiga, kesantunan itu dikaitkan dengan hak dan kewajiban penyerta interaksi. Artinya, apakah sebuah ujaran terdengar santun atau tidak, ini "diukur" berdasarkan (1) apakah Pn tidak melampaui haknya kepada Mt dan (2) apakah di Pn memenuhi kewajibannya kepada Mt. Menurut Mulder (1973), keadaan komunikatif terdapat di mana semua pihak berada dalam keadaan damai satu sama lain, suka bekerja sama, saling menerima, dalam suasana tenang dan sepakat. Pendapat Mulder ini diperkuat oleh pernyataan Geertz (1967) bahwa berlaku komunikasi yang komunikatif berarti menghilangkan tanda-tanda ketegangan dalam masyarakat atau antara pribadi-pribadi sebagai hubungan-hubungan sosial tetap kelihatan selaras dan baik-baik. Menurut Brown dan Levinson prinsip kerja sama sebagaimana yang dikemukakan Grice dalam komunikasi, sesungguhnya sering dilanggar atau tidak dipatuhi oleh para peserta mtur. Hal ini disebabkan karena di dalam berkomunikasi tujuan kita tidak hanya menyampaikan informasi saja, melainkan juga untuk menjaga atau memelihara hubunganhubungan sosial antara Pn dan Mt (walaupun ada peristiwa-peristiwa tutur tertentu yang tidak menuntut pemeliharaan hubungan itu). Kebutuhan noninformarif ini termasuk dalam kebutuhan komunikatif yang bersifat umum.

Dilihat dari proses pernilihan strategi dalam berkomunikasi, maka dalam bertutur sapa merupakan suatu upaya unmk menyatukan hubungan antara seseorang dengan orang lain yang bisa saja terjadi pelanggaran-pelanggaran kesantunan. Dalam kaitan ini apabila seseorang berbicara tidak selalu berkaitan dengan masalah tekstaal, akan tetapi sering berhubungan dengan persoalan yang bersifat interpersonal. Untuk memperlancar suatu komunikasi, prakmatik memerlukan prinsip kerja sama dan sebagai interpersonal prakmatik membutuhkan prinsip lain yaitu prinsip kesantunan. Prinsip kesantunan mempunyai sejumlah maksim, yakni maksim kebijaksanaan (tact maxim), maksim penerimaan \{generosity maxim), kemurahan maksim \{approbation maxim), maksim kerendahan hati (modesty maxim), maksim kecocokan (agreement maxim), maksim kesimpatian (simphathy maxim). Prinsip kesopanan ini berlaku dalam suatu komunikasi. Skala kesantunan merupakan peringkat kesantunan yang dimulai dari tuturan yang tidak santun sampai dengan yang paling santun. Berikut uraian skala kesantunan Leech dan Brown dan Levinson. Baik kesantunan yang mendasarkan pada maksim percakapan maupun pandangan kesantunan yang mendasarkan pada konsep penyelamatan muka, keduanya dapat dikatakan memiliki kesejajaran. Kesejajaran itu tampak dalam hal penentuan tindakan yang sifatnya tidak santun atau tindakan yang mengancam muka dan tindakan santun atau tindakan yang tidak mengancam muka. Brown dan Levinson (1987), melihat kesantunan berbahasa merupakan sebuah sistem yang kompleks unmk memperhalus ujaran yang mengancam muka (face-threatening act) atau FTA. Holmes (1992) menyatakan bahwa kesantunan merupakan sesuatu yang sangat kompleks dalam berbahasa, karena tidak hanya melibatkan pemahaman aspek kebahasaan saja. Kesantunan berbahasa tidak hanya berhubungan dengan pemahaman bagaimana mengucapkan silakan dan terima kasih secara tepat, akan tetapi perlu juga 
pemahaman nilai budaya suatu masyarakat tatur. Brown dan Levinson mengemukakan dua hal tentang teori kesantunan yaitu: rasionalitas dan muka. Kedua hal tersebut sebagai ciri umum yang dimiliki oleh penutur $(\mathrm{Pn})$ dan mitra tatur $(\mathrm{Mt})$ yang diwujudkan dalam pribadi model atau model personal (MP). RasionaUtas merupakan logika atau penalaran sarana tujuan, sedangkan muka sebagai citra diriyang terdiri dari dua keinginan yang berlawanan, yaitu muka positif dan muka negatif. Muka poositif adalah keinginan agar seseorang disegani oleh orang lain, sedangkan muka negatif adalah keinginan agar tindakan seseorang tidak dihalangi oleh orang lain. Brown dan Levinson (1987) menyatakan bahwa dalam melakukan FTA seorang MP dapat menggunakan salah satu dari lima strategi yang ditawarkan yaitu (1) melakukan tindak mtur secara langsung atau apa adanya tanpa basa-basi (bald on record), (2) melakukan tindak mtur dengan menggunakan strategi kesantunan positif, (3) melakukan tindak mtur dengan kesantunan negatif, (4) melakukan tindak mtur secara tersamar atau tidak langsung (off record), dan (5) bertutur dalam hati atau tidak melakukan tindak mtur. Berdasarkan strategi kesantunan positif (Brown dan Levinson, 1987) menjabarkan 15 strategi yang dapat dipakai oleh seorang MP, yaitu: (1) Memperhatikan kesukaan, keinginan, dan kebutuhan Mt, (2) membesarbesarkan perhatian, persetujuan, dan simpati kepada Mt, (3) mengintensifkan perhatian Mt dengan pendramatisiran peristiwa atau fakta, (4) menggunakan identitas kelompok (bentuk sapaan, dialek, jargon, atau slang), (5) mencari persetujuan dengan topik yang umum atau mengulang sebagian atau seluruh ujaran, (6) menghindari ketidaksetujuan dengan pura-pura setuju, persetujuan yang semu (pseudoagreement), menipu unmk kebaikan (white-lies), pemagaran opini (hedging opinions), (7) menunjukkan hal-hal yang dianggap mempunyai kesamaan melalui basa-basi (small talk) dan presuposisi, (8) menggunakan lelucon, (9) menyatakan paham akan keinginan Mt, (10) memberikan tawaran atau janji, (11) menunjukkan keoptimisan, (12) mekbatkan Pn dan Mt dalam aktivitas, (13) memberikan pertanyaan atau meminta alasan, 14) menyatakan hubungan secara timbal balik resiprokal), dan (15) berikan hadiah (barang, simpati, perhatian, kerja sama) kepada Mt. Berdasarkan strategi kesantunan negatif, Brown dan Levinson (1987) menjabarkan menjadi delapan strategi, yaitu: (1) Pakailah ujaran tidak langsung (yang secara konvensional dipakai oleh masyarakat yang bersangkutan), (2) pakailah pagar (hedge), (3) tunjukkan pesimisme, (4) rrunimalkan paksaan,
(5) berikan penghormatan, 6) mintalah maaf, (7) pakailah bentuk impersonal yaitu dengan tidak menyebutkan Pn dan Mt), dan (8) ujaran tindak tutur itu sebagai ketentuan yang bersifat umum. (9) meminta alasan atau memberikan pertanyaan, dan (10) memberikan hadiah.

Banyak model atau cara yang dipakai untuk mencapai kesantunan. Salah satu model vang dikemukakan oleh Haose dan Kasper dalam Waat, yang dikutip Murni berupa tipologi ungkapan yang sering digunakan sebagai penanda kesanmnan linguistik, yang dapat disusun dalam taksonomi sebagai berikut. Penanda kesanmnan Unguistik (politeness markers), (2) Perangkat sintaksis (Play-downs), (3) Perangkat konsultatif \{consultative device), (4) kata berpagar (Hedges), (5) Pengecil (Understaters), Penurun (Downtoners), (7) Perujuk diri (Committers), (8) Pengingat (forewarning), (9) Penunda (Hesitator), (10) Scope-staters, yang mengungkapkan pendapat subjektif tentang sifat keadaan (11) Agent avoiders (penghindaran), (12) Cajolers (pembujuk), (13) appealers (penyeru), (14) Pengarah (steers), (15) pelatar (graunders), (16) Pengancang (preparators).

Taksonomi sttukturkesanmnanUnguistik menjadi acuan dalam menginterpretasikan kesanmnan interaksi komunikasi sivitas akademika universitas Bengkulu. Di samping im penggunaan bentuk linguistik tertentu yang potensial dalam masyarakat juga perlu diperhatikan. Sebagai contoh pemakaian pronorrrina yang digunakan dalam masyarakat Timur. Hal ini sejalan dengan apa yang dikemukakan oleh Muhlhausler dan Harre (1976), yang mengemukakan bahwa penggunaan kata ganti dapat mencerminkan bagaimana seseorang melihat dirinya dalam hubungan sosialnya dengan orang lain. Hubungan sosial tersebut bisa sebagai atasan dan bawahan atau sesama kawan. Kedua hal tersebut bisa menggunakan pronomina jamak atau pronomina orang ketiga, seperti penggunaan we atau kami.

Penelitian ini bermjuan mendapatkan pemahaman yang memadai tentang kesantunan berbahasa di lingkungan sivitas akademika Universitas Bengkulu. Pemahaman akan kesantunan akan menunjang keberhasilan dalam prestasi akademik dan memperlancar komunikasi.

Penelitian tentang kesanmnan telah menggejalan dalam berbagai disiplin meski Brown dan Levinson berbasis teori linguistik. Berkaitan dengan penektian ini Brunet (et al., 2011) telah mengkaji hubungan kesanmnan dengan sinyal sosial. 


\section{METODE}

Penektian ini mengacu metode penektian Sugiyono (2008: 6), yang mengemukakan cara ilmiah mendapatkan data yang vakd yang dapat dikemukakan, dikembangkan, dan dibuktikan suam pengetahuan tertentu unmk dipakai sebagai cara memahami, memecahkan, dan mengantisipasi masalah. Tujuan penektian ini adalah unmk mendapatkan pemahaman yang memadai tentang kesantunan berbahasa di lingkungan sivitas akademika Universitas Bengkulu. Metode yang digunakan adalah anaksis isi \{content analysis) yang menganaksis kecenderungan (trends) dan pola (patterns) (Krippendorf, 1991) yang ditentukan olehrteori kesanmnan berbahasa dalam berkomunikasi.

Menurut Emzir (2010: 37) observasi, wawancara, dokumen pribadi dan resmi, foto, rekaman, gambar, dan percakapan informal semua merupakan sumber data kuaktatif. Dalam penektian ini yang dijadikan sebagai sumber data adalah rekaman interaksi komunikasi di lingkungan Unib. Data yang dikumpulkan unmk penektian ini adalah data-data yang diperoleh melalui rekaman dari interaksi komunikasi berupa diskusi-diskusi, rapat-rapat yang diselenggarakan oleh civitas akademika universitas Bengkulu, mahasiswa dan dosen, yang ada di lingkungan Universitas Bengkulu.

Sumber data yang digunakan dalam penektian ini adalah data primer, yaitu data yang secara langsung berkaitan atau berkenaan dengan masalah yang ditekti dan secara langsung dari sumber. Sumber tersebut berupa diskusi kelas, pendadaran dan rapat yang di dalamnya mengandung kesanmnan. Sumber data, pada awalnya terkumpul sebanyak 20 rekaman, akan tetapi setelah direduksi diperoleh data sebanyak 9 rekaman yang memenuhi persyaratan. Data yang sudah dikumpulkan berupa interaksi komunikasi antara mahasiswa dengan mahasiswa, dosen dengan dosen dan mahasiswa dengan dosen yang mengandung kesantunan berbahasa. Menurut Emzk (2010: 37) observasi, wawancara, dokumen pribadi dan resmi, foto, rekaman, gambar, dan percakapan informal semua merupakan sumber data kuaktatif. Dalam penektian ini yang dijadikan sebagai sumber data adalah rekaman interaksi komunikasi sivitas akademika Universitas Bengkulu. Data yang dikumpulkan unmk penektian ini adalah data-data yang diperoleh melalui teknik rekaman dari interaksi komunikasi berupa diskusi-diskusi, rapat-rapat yang diselenggarakan oleh sivitas akademika universitas Bengkulu, baik mahasiswa dan dosen, yang ada di lingkungan Universitas Bengkulu.

Pengumpulan data dilakukan dengan menggunakan metode simak (Mahsun, 2005: 90). Metode ini dapat disejajarkan dengan metode pengamatan atau observasi dalam iknu sosial, terutama antropologi. Metode ini dapat dijabarkan menjadi wujud teknik penyadapan dan teknik lanjutan berupa: (1) berpartisipasi sambil menyimak, (2) perekaman, dan (3) pencataatan pada kartu (Sudaryanto, 1993: 28). Data dianaksis dengan prinsip maksim Grice.

\section{HASIL DAN PEMBAHASAN}

Hasil penelitian atau temuan-temuan yang diperoleh dari penektian yang sudah dilakukan dan dideskripsikan, selanjutnya akan dibahas sesuai dengan fokus dan subfokus penektian. Subfokus penektian dalam interaksi komunikasi di lingkungan Universitas bengkulu, mencakup permasalahan yaitu: (1) Pemenuhan prinsip maksim kesantunan berbahasa, (2) pelanggaran prinsip maksim kesanmnan berbahasa dalam interaksi di lingkungan civitas akademika Universitas Bengkulu. Kedua hal tersebut akan dibahas satu per satu sebagai berikut: (1) Pemenuhan prinsip kesanmnan dalam interaksi komunikasi di lingkungan sivitas akademika Universitas Bengkulu, tidak banyak ditemukan. Data yang diperoleh sebanyak 28 pasangan tuturan dari sebanyak 316 data ujaran, maka didapatkan hasil kemunculan sebesar 8,9\%. Hasil tersebut terdiri dari (1) pemenuhan maksim kemurahan 10 pasang tuturan, (2) pemenuhan maksim kesetujuan 8 pasang tuturan, (3) maksim kesimpatian 3 pasang tuturan, (4) maksim kerendahan hati 4 pasang tuturan, dan (5) maksim penerimaan 2 pasang tuturan.

Pemenuhan maksim penerimaan menggambarkan adanya penuturan yang baik antara penutur dengan mitra tuturnya, namun 
demikian data yang diperoleh dalam penektian ini tidak banyak dan hanya menyatakan kesediaan unmk menjawab pertanyaan yang disampaikan oleh dosen terhadap mahasiswa. Leech (1982: 132) menggambarkan bahwa maksim penerimaan menginginkan setiap peserta tuturan untuk memaksimalkan kerugian bagi dki sendiri dan meminimalkan keuntungan bagi did sendiri. Pertuturan yang menunjukkan adanya maksim penerimaan seperti pada gikran tuturan (64) dan (65) yaitu: tuturan tersebut dimulai dengan pembukaan yang menyatakan salam hormat dan dilanjutkaan dengan pernyataan bahwa para mahasiswa sudah melaksanakan KKN selama 2 bulan sehingga mahasiswa dapat menggambarkan atau menceritakan kembak apa yang sudah dilakukan selama melaksanakan $\mathrm{KKN}$ tersebut dengan menjawab pertanyaan yang diajukan oleh dosen penguji pendadaran. Pertanyaan tersebut dimulai dengan ucapan pada (64) D: Oke Anda siap menerima pertanyaan? (65) M: ya, siap pak. Tuturan tersebut menunjukkan adanya pemenuhan maksim kesanmnan, karena (D) menanyakan kesiapan kepada para mahasiswa untuk menjawab pertanyaan yang diajukan dan dijawab (M) dengan ya, siap pak. Ini menunjukkan bahwa (M) memaksimalkan kerugian bagi diri sendiri dan meminimalkan keuntungan diri sendiri. Tuturan tersebut dapat dikatakan tidak santun apabila (M) menjawab dengan ucapan belum, pak, maka tentu (D) tidak akan melanjutkan acara pendadaran tersebut, sehingga (D) telah membuat sebesar-besarnya kerugian diri sendiri.

Pemenuhan maksim kemurahan dapat digambarkan pada permmran yang saling memberikan penghormatan berupa doa keselamatan pada permmran tersebut, sehingga masing-masing penutur maupun mitra tutur saling memberikan doa keselamatan. Kondisi seperti ini terlihat pada data (16) dan (17) di mana pada tuturan (16) penutur (M) mendapat giliran untuk bertanya dalam suatu diskusi dan unmk memulai pertanyaannya terlebih dahulu memberikan ucapan Assalamualaikum warahmatullahi wabarakamh. Ucapan seperti ini memberi gambaran bahwa penumr lebih dahulu memberikan doa keselamatan yang dalam bahasa Indonesia mudah-mudahan keselamatan dan barakah ada pada dirimu. Ucapan seperti ini menunjukkan rasa kemurahan pada mitra tuturnya, yang walaupun doa semacam ini merupakan doa yang biasa diucapkan oleh seorang muslim pada muslim yang lain, akan tetapi dalam kondisi di Indonesia ucapan salam semacam ini sudah menjadi tradisi nasional, sehinga tidak khusus disampaikan pada kaum muslim saja tetapi bisa dipakai unmk seluruh masyarakat Indonesia. Ucapan salam tersebut disambut dengan antusias oleh peserta diskusi (audien) (M) atau mitra tuturnya dengan ucapan waalaikum salam warahmatullahi wabarakamh. Ucapan demikian juga mengandung makna mudah-mudahan keselamatan dan barakah juga diberikan pada dirimu. Ujaran seperti ini menunjukkan bahwa (M) sebagai penumr telah memaksimalkan rasa hormatnya kepada orang lain dengan penghormatan berupa doa keselamatan.

Ujaran yang disampaikan (M) dalam suatu interaksi komunikasi dengan mengucapkan kata maaf unmk menyebut sesuatu yang tabu merupakan suatu ungkapan yang santun, karena penyebutan sesuatu yang sifatnya tabu tidak bisa atau tidak baik apabila dikatakan secara langsung, sehingga menggunakan kata maaf sebagai ungkapan yang santun. Pernyataan ini dapat dilihat pada data (287) dan (288) yakni (M) menjawab dengan ujaran: Dampaknya bisa saja wanita tersebut merasa risih dan tidak nyaman. Apabila penyakit keputiban tersebut terlalu parah, maka si penderita akan mengalamigatal-gatan di.. (maaf) organ kewwanitaannya. Secara tidak langsung tindak tutur tersebut telah memaksimalkan ketidakhormatan pada diri sendiri dan memaksimalkan rasa hormat pada diri sendiri.

Pernyataan rasa terima kasih merupakan bentuk pengungkapan yang santun dalam suatu pertemuan yang diungkapkan pada pertuturan (05) Dan (06) dengan ujaran: Bagaimana Saudara Fitri. Dijawab oleh (M) dengan ucapan: Sudah, terima kasib. Hal ini diucapkan untuk menerima 
jawaban yang disampaikan oleh mitra tuturnya sebagai rasa kecocokan. Maksim kecocokan menggariskan setiap penutur dan mitra mtur untuk memaksimalkan kecocokan di antara mereka dan meminimalkan ketidakcocokan di antara mereka.

Ungkapan rasa kesimpatian merupakan bentuk kesantunan yang disampaikan penutur terhadap mitra tuturnya. Maksim kesimpatian menggariskan setiap pserta tutur untuk memaksimalkan rasa simpati dan meminimalkan rasa antipati kepada mitra mturnya. Pertuturan yang menyatakan rasa kesimpatian dalam penektian ini daperoleh data sebanyak 3 buah, yang kesemuanya disampaikan oleh (D) sebagai harapan dan simpati kepada (M) agar dapat berhasil dalam smdinya, seperti pada ujaran (132) dan (133) dengan ujaran (D):Demikianlah para mahasiswa pendadaran ini sudah kita laksanakan, bapak harapkan Anda dapat lakukan lebih baik dalam kehidupan bermasyarakat, lebih pandai lagi mendekati masyarakat, dan semoga Anda lulus semua. Ujaran tersebut disambut dengan serentak oleh (M) dengan ucapan Amin. Dengan demikian permmran tersebut memberi gambaran bahwa penutur memaksimalkan rasa simpati dan meminimalkan rasa antipati kepada $(\mathrm{M})$.

Interaksi komunikasi merupakan proses komunikasi yang mengacu pada tindakan seseorang unmk mengirim atau menerima pesan dalam suatu tindak mtur. Proses komunikasi yang baik menghasilkan suatu tuturan yang baik dan dapat mengakibatkan suatu tuturan yang santun. Namun demikian bila permmran tersebut tidak terjadi keharmonisan, maka bisa berakibat permmran tersebut menjadi tidak santun.

Pertuturan yang terjadi dalam suatu interaksi komunikasi di lingkungan sivitas akademika Universitas bengkulu dalam pelanggaran maksim kesanmnan dapat diuraikan sebagai berikut: Pelanggaran maksim secara keseluruhan senanyak 27 pertuturan yang dapat ckrinci sebagai berikut. (1) Pelanggaran maksim kebijaksanaan sebanyak 2 pasang tuturan atau 7\%, (2) pelanggaran maksim penerimaan sebanyak 2 pasang ujaran atau 7\%,(3) pelanggaran maksim kerendahan hati sebanyak 1 pasang ujaran atau 4\%, (4) pelanggaran maksim kesetujuan sebanyak 1 pasang ujaran atau 4\%, dan (5) pelanggaran maksim kesimpatian paling banyak yakni 21 pasang ujaran atau 78\%.

Maksim kebijaksanaan mengharuskan setiap penutur meminimalkan kerugian bagi mitra tuturnya atau orang lain, atau memaksimalkan keuntungan bagi rriira mtur atau orang lain. Hal ini dilakukan sebagai penghargaan bagi orang lain. Akan tetapi dalam interaksi komunikasi civitas akademika Universitas Bengkulu terdapat pelanggaran atas maksim kebijaksanaan yang terjadi ketika terjadi interaksi antara (D) dengan (M) dalam suatu diskusi, di mana (D) pada ujaran (36), yakni dosen menyuruh (M) unmk membuka skde yang sudah terlewati dengan ujaran: Ok...nab itu tadi, buka slide yang .. nah itu dia. Nab itu nama itu anda membacanya seperti opal... menurut... yang dijawab oleb (M) (37) Djajasudarma Qajasudarma), lalu dibenarkan menjadi Djajasudarma Qayasudarma). Permmran tersebut melanggar maksim kebijaksanaan, karena (D) langsung memerintahkan unmk membuka skde, yang seharusnya dapat diucapkan coba anda buka slide tadi. Dengan ujaran tersebut, bahwa (D) menyatakan ketidaksanmnannya kepada (M) yang bertindak sebagai mitra mturnya.

Maksim penerimaan mengharuskan penumr unmk selalu memaksimalkan kerugian pada diri sendiri dan meminimalkan keuntungan pada diri sendiri. Kondisi seperti ini dalam interaksi komunikasi civitas akademika Universitas Bengkulu terjadi pelanggaran atau penyimpangan terhadap maksim penerimaan, sehingga penutur berbuat memaksimalkan keuntungan pada diri sendiri.dengan bentuk mendahului ujaran yang dilakukan oleh seorang moderator yang memimpin jalannya diskusi, seperti ujaran (08) menjawab pertanyaan $(\mathrm{M})$, yang seharusnya diserahkan pada moderator, tetapi (M) langsung bertanya kembak, sehingga melanggar prinsip kesanmnan yakni maksim penerimaan.

Pelanggaran terhadap maksim kerendahan hati dalam interaksi komunikasi civitas akademika di Universitas Bengkulu menggambarkan rasa kesombongan atau keangkuhan yang terdapat 
dalam tuturan yang diujarkan (76) D:.Anda pasti bohong atau bohong. Jadi kalau bapak ke sana rengginan itu ada? Pernyataan anda pasti bohong menunjukan adanya ketidaksantunan dalam bertutur, karena tidak didasari fakta yang jelas dan seakan menuduh mitra mturnya yang melakukan kebohongan.

Pelanggaran maksim kecocokan menjadikan permmran tersebut menjadi tidak cocok. Dalam interaksi komunikasi para civitas akademika Universitas Bengkulu terjadi dalam suatu diskusi antara (M) sebagai penanya dengan jawaban vang diberikan $(\mathrm{M})$, namun jawaban tersebut belum memuaskan, sehingga muncul perkataan masih bingung. Ujaran tersebut memberikan gambaran bahwa tuturan tersebut menjadikan ketidakcocokan dalam interaksi komunikasi, sehingga melanggar maksim kecocokan.

Pelanggaran Maksim kesimpatian merupakan maksim yang tidak bersifat simpati. Maksim kesimpatian dapat dipenuhi apabila penutur dan mitra mtur memaksimalkan rasa simpati, dan meminimalkan rasa antipati di antara mereka. Ujaran yang menunjukkan adanya ketidaksimpatian merupakan bentuk ujaran yang menggunakan pronomina ujaran kamu sebagai bentuk sapaan pada mitra mturnya. Bentuk sapaan kamu, akan terlihat santun apabila diubah menjadi sebutan Anda atau Saudara. Sebutan kamu memberi kesan bahwa penutur tidak memikki rasa simpati, karena yang disebut adalah orang yang sudah dewasa, sehingga menyebabkan ketidaksimpatian terhadap mitra mtur, dan dapat dikategorikan sebagai melanggar maksim kesimpatian.

Komunikasi memerlukan upaya keselarasan vang harus diwujudkan oleh penumr maupun mitra mtur. Keselarasan tersebut menjadikan suatu komunikasi itu menjadi komunikatif. Dalam suatu komunikasi diperlukan suatu pokok pembicaraan. Hal ini diperlukan unmk membuat suatu strategi dalam suatu komunikasi. Dengan demikian dalam komunikasi baik penumr maupun mitra mtur berusaha unmk membuat suatu tuturan tersebut membuat orang lain atau mitra tutur menjadi senang, akan tetapi terkadang apa yang diucapkan dapat menjadikan seseorang merasa tidak berkenan yang sering diistilahkan sebagai Face Treatening Acts yang dimaknai sebagai tindakan mengancam muka.

Berdasarkan analisis pelanggaran prinsip kesantunan berbahasa

bahwa dalam interaksi Komunikasi di lingkungan civitas akademika Universitas Bengkulu ditemukan 27 pasangan ujaran. Pasangan ujaran tersebut sebanyak 2 pasangan ujaran atau sebesar 7\% unmk pelanggaran prinsip kebijaksanaan. Sebanyak 2 pasangan ujaran atau sebesar $7 \%$ unmk pelanggaran prinsip penerimaan. Pelanggaran prinsip kemurahan tidak ditemukan data. Pelanggaran prinsip kerendahan hati sebanyak 1 pasang ujaran atau sebesar 4\%, dan ditemukan pelanggaran prinsip kesetujuan sebanyak 1 pasang ujaran atau sebesar 4\%. Pelanggaran prinsip kesimpatian sebanyak 21 pasang ujaran atau sebesar $78 \%$.

Berdasarkan data tersebut pelanggaran Prinsip kesimpatian mendominasi pelanggaran prinsip kesanmnan berbahasa dengan permunculan sebanyak $78 \%$, sedangkan yang paling sedikit adalah prinsip kemurahan dan kerendahan hati, masing-masing 1 pasang ujaran atau sebanyak $4 \%$.

Pelanggaran maksim kebijaksanaan dengan menyuruh langsung yangmerupakan pelanggaran maksim. Pelanggaran maksim penerimaan berupa penyampaian jawaban yang kurang sesuai, sehingga bertanya kembak tanpa melalui moderator. Pelanggaran maksim kerendahan hati dalam bentuk ucapan anda bohong, yang menggambarkan ketidak santunan dalam bertutur sapa, sehingga melanggar maksim kerendahan hati. Pelanggaran maksim kesimpatian berupa bentuk sapaan kamu. Hal ini merupakan pelanggaran maksim, karena bentuk panggilan tersebut kurang baik diujarkan kepada anak muda atau orang yang lebih ma.

Berdasarkan hasil penektian yang telah penulis per oleh, banyak hal yang perlu direkomendasikan, sehingga penelitian ini lebih bermakna dalam mengupayakan keadaan 
kesantunan berbahasa di lingkungan civitas akademika Universitas Bengkulu.

Adapun rekomendasi yang penulis ajukan: (1) Para dosen maupun para pemegang jabatan di Universitas Bengkulu, hendaknya dapat mengupayakan dan memberi teladan kepada para mahasiswa atau civitas akademika Universitas Bengkulu dalam bertutur sapa, sehingga kesanmnan dalam berkomunikasi tetap terjaga; (2) Penektian yang penuks lakukan hanya sebatas pada interaksi komunikasi, sehingga perlu dilakukan penektian lanjutan yang menggarap kesanmnan berbahasa dalam situasi yang tidak formal.

Rekomendasi berikutnya terkait dengan pemanfaatan hasil penektian bagi pengembangan mata kukah seperti mata kukah keterampilan berbahasa yang memanfaatkan teori pragmatik dan kesantunan berbahasa. Pengembangan mata kukah ini mencakup pengembangan materi perkukahan berdasarkan temuan penektian ini. Dengan demikian maka penektian dan pengajaran saling berkontribusi positif untuk peningkatan mum berkelanjutan.

\section{DAFT A R PUSTAKA}

Achmad HP. Teori Kesantunan Berbabasa, (Disampaikan pada Pertemuan Masyarakat Linguistik Indonesia 'MLF Komisariat Universitas Negeri Jakarta: 26 April 2002).

Beckett, Samuel. 1974. Text for Nothing. London: Clader 7 Boyars.

Brown, P., S. Levinson. 1978. "Universals in Language Usage: Pokteness Phenomena" dalam E.N. Goody (ed.). Questions and Politeness in Social Interaction. Cambridge: CUP. Brown, P., S. Levinson. 1996. Politeness, Some Universals in Language Usage. Cambridge: CUP.

Brunet, Paul M., Ellen Douglas-Cowie, Roderick Cowie, Hastings Donnan. Pokteness and Social Signals. Springer. Pubksh online 8 Oktober 2011.
Chaer, Abdul dan Agustina, Leoni. 1993. SosiolinguistibPerkenalan Awal. Jakarta: Rineka Cipta.

Chaer, Abdul. 2010. Kesantunan Berbahasa. Jakarta: Rineka Cipta.

Dijk, Teun A. van. 1977. Text and Context, Exploration in the Semantics and Pragmatics of Discourse. London: Longman Group Ltd.

Djajasudarma, T. Fatimah. 1994. Wacana. Pemabaman dan Hubungan Antarunsur. Bandung: Eresco.

Eelen, Gino. 2001. A Critique of Politeness Theory. Manchester, UK: St. Jerome. Emzk. 2010. MetodologiPenelitian Kualitatif.Analisis Data. Jakarta: Raja Grafindo Persada.

Eriyanto. 2001. Analisis Wacana: PengantarAnalisis Teks Media. Yogyakarta: LkiS.

Fraser, M. 1978. Acquiring Social Competence in a Second Languange, RELC Journal.

Geertz.C, 1967. Linguistic etiquette, dalam Geertz, C, Relegion of Java, New York: Glencoe Prees.

Grice, H.P 1981. "Presupposition and Conversational Impkcature" dalam Cole, P. (ed.) Radical Pragmatics. New York: Academic Press.

Halkday, M.A.K. 1981. An Introduction to Functional Grammar. London: Edward Arnold.

Hymes, DeU. 1974. Foundations in Sociolinguistics: An Ethnographic Approach. Philadelphia: University of Pennsylvania Press.

Huberman dan Miles. 1994. Analisis Data Kualitatif. Buku Sumber tentang metodemetode baru. Terjemahan Tjetjep Rohendi Rohadi, Jakarta: UI Press.

Ibrahim, Abdul Syukur. 1994. Panduan Penelitian

Etnografi Komunikasi. Surabaya: Usaha Nasional.

Krippendorf, Klaus. 1991. Analisis Isi. Jakarta: Rajawak.

Lakoff, R. 1973. The logic of pokteness; or minding your p's and q Chicago Linguistics Society, 8: 292-305. 
Lakoff, R. 1975. Language and woman's place. New York: Harper. Lakoff, R. \& Ide, S. (Eds). 2005. Broadening the horizon of linguistic politeness. Amsterdam: John Benjamins.

Lauder, Multamia R.M.T. 1998. "Pengembangan bahasa Indonesia Melalui Penelitian" dalam Bahasa Indonesia Menjelang Tabun 2000. Jakarta: Pusat Pembinaan dan Pengembangan Bahasa, Depdikbud.

Leech, Geoffrey. 1982. Principles of Pragmatiics. London and New York: Longman.

Mahsun. 2005. Metode Penelitian Bahasa. Yogyakarta: Duta Wacana University Press. McCarthy, M. 1991. Discourse Analysisfor Language Teachers. Cambridge: CUP.

Mey, Jacob L. 1994. Pragmatics: Anlntroduction. Oxford UK \& Cambrigde USA: Black Well.

Pateda Mansyur. 1987. Sosiolinguistik. Bandung: Angkasa.

Ricouer, P. 1996. Interpretation Theory: Discourse and Surplus Meaning (Terj.). Jakarta: P3B Depdikbud.
Rusbiantoro, Dadang. 2001. Bahasa Dekonstruksi ala Foucault dan Derrida. Yogyakarta: Tiara wacana.

Searle, John. 1969. Speech Act: Essay in the Philosophy Description Cambridge: Cambridge University Prees.

Sobur, Alex. 2001. Analisis Teks Media. Bandung: Remaja Rosdakarya.

Stern, H.H. 1984. Fundamental Concepts of Languagen Teaching. Oxford: Oxford University Press.

Sudaryanto. 1993. Metode dan Aneka Teknik Analisis Bahasa. Yogyakarta: Duta Wacana University Press.

Sugiyono. 2008. Metode Penelitian pendidikan (Pendekatan Kuantitatif Kualitatif dan R\&D). Bandung: Alfabeta.

Uchyana Effendy Onong. 2006. Ilmu Komunikasi Teori dan Praktek. Bandung: Rosda. Watts,

Richard. J. 2003. Politeness. Cambridge: Cambridge University Press.

Watts, R. J., Ide, S., \& Ehkch, K. 1992. Politenessin language: Studies in its history, theory and practice. Berlin: Mounton de Gruyter. 